\title{
ПРОБЛЕМА ПРАВОВОӤ ВИЗНАЧЕНОСТІ УНІКАЛЬНИХ ДОКУМЕНТІВ НАЦІОНАЛЬНОГО АРХІВНОГО ФОНДУ
}

\author{
ПОПОВА Лілія Миколаївна - доктор юридичних наук, доцент, професор \\ кафедри фінансів та кредиту Харківського національного університету \\ будівництва та архітектури (м. Харків, Україна) \\ ORCID: https://orcid.org/0000-0001-8255-8363; \\ ХРОМОВ Анатолій Володимирович - кандидат історичних наук, голова \\ Державної архівної служби України (м. Київ, Україна) \\ ORCID: https://orcid.org/0000-0002-9546-7089; \\ УДК: 342 : 651.5 : 004 \\ DOI 10.32782/NP.2021.1.1
}

Понятие «Уникальнъй документ Национального архивного фонда» является одним из основньгх в категориальном аппарате архивистов Украинъл. Одной из ключевъхх задач сети государственнъгх архивов, Государственной архивной службъ Украинъ является постояннъй отбор, утверждение статуса и обеспечение учета и хранения уникальных документов Национального архивного бонда (НАФ). Реалии такой работъи констатируют наличие проблемъ недостаточной правовой определенности этой категории. Целью исследования является характеристика и анализ механизма отнесения документов НАФ к уникальныл, их учета и хранения. Результат исследования заключается в обосновании необходимости внесения изменений в категориальньй аппарат отраслевого архивного закона и подзаконных актов. Въгводъ. Установлено, ито после обретения Украиной независимости законодателю понадобилось более 2 лет для принятия пробильного архивного закона, которыл в частности определено отдельную категорию уникальных документов НАФ. Эта достаточно узкая группа исторических памятников имеет важное значение для развития архивной отрасли странъ, одновременно механизм отнесения архивных документов к НАФ является несовершеннълм, в том иисле из-за проблемъ недостаточной правовой определенности понятий. Для решения этой проблемъ предложено в архивное законодательство ввести новое понятие «уникальный памятник На- циональных архивньх инббормачионньхх ресурсов».

Ключевъе слова: уникальный документ, уникальнъий памятник, Национальнълй архивный бонд, Начиональные архивнъие инбормачионнъле ресурсы, правовая определенность, Государственная архивная служба Украинъ, экспертиза иенности.

\section{Постановка проблеми}

Принцип правової визначеності (певності) належить до загальних принципів права, який має гарантувати достатню легкість сприйняття, з' ясування змісту права i можливість за потреби ним скористатися. Тому для забезпечення ефективного регулювання суспільних відносин право повинно бути доступним, універсальним та зрозумілим як для посадових осіб, так і доступним для сприйняття пересічними громадянами.

Недоліки формулювання, суперечність трактування норм права призводять до проблем праворозуміння, які ще більше посилюються на етапі правозастосування. Завадити таким проблемам має правова визначеність як принцип права і як вимога до права. Кінцевою метою нормотворчості має стати єдність праворозуміння, відсутність двоякого, ситуативного тлумачення змісту правової норми.

На наявність цих проблем в українському законодавстві неодноразово вказувалось як у галузевих, так і в загальноправових дослідженнях. До терміна «правова визна- 


\section{Теорія, історія держави і права, конституційне право}

ченість» у своїх дослідженнях звертались такі науковці-правники, як М. Козюбра [1], О. Мусиченко [2], С. Погребняк [3], Г. Огнев'юк [4] та інші. Так само існує достатній доробок учених-архівознавців у частині розробки галузевої термінології аналізу архівних норм права, зокрема в роботах К. Новохатського [5], I. Матяш [6], Г. Боряка [7] та інших. Але наразі відсутні комплексні дослідження щодо проблеми правової визначеності норм архівного українського законодавства щодо виокремлення унікальних архівних пам'яток.

Міжнародне співтовариство ставить доволі високі вимоги до якості законів, ясності їхнього формулювання, правильного тлумачення та коректного застосування. Венеціанська комісія у своїй доповіді від 04 квітня 2011 року «Верховенство права» вказала, що правова визначеність є елементом верховенства права [8]. Практика роботи державних архівних установ та колегіальних дорадчих органів свідчить про присутність проблеми поліваріантності тлумачення поняття унікальний документ Національного архівного фонду (НАФ) та проблем його правозастосування щодо архівних документів на різних носіях, окремих архівних справ чи цілих комплексів зберігання (фондів, колекцій). Вирішення цього питання $є$ не лише теоретичною дилемою, але і важливим завданням Державної архівної служби України - центрального органу виконавчої влади, який реалізує державну політику в архівній сфері.

Місце унікальних документів в архівні справі та архівному законодавстві

У системі державних архівних установ України зберігається більше 82 мільйонів одиниць (справ) Національного архівного фонду. Точна кількість документів у цих справах необлікована, але вірогідно, що мова йде про сотні мільйонів або навіть більше мільярда архівних документів. Серед цього величезного комплексу історичних пам'яток до унікальних віднесено вже 440 архівних документів [9]. 3 них більшість - 367 - зберігаються в центральних державних архівах, 73 в державних архівах областей [10, с. 20-26]. Лідером серед державних архівів щодо наявності унікальних документів є Центральний державний icторичний архів України, м. Аьвів. Він зберігає 320 унікальних документів. Зокрема, архів зберігає найдавніші унікальні документи НАФ - це колекція берестяних грамот, які датуються початком XII століття [11], [12], [13]. Найпізнішим з унікальних документів наразі визнано оригінальний текст Конституції України 1996 року [14].

Статтею 1 Закону України «Про Національний архівний фонд та архівні установи» встановлено, що унікальний документ - документ НАФ, який має виняткову культурну цінність та важливе значення для формування національної самосвідомості Українського народу, а також визначає його вклад у всесвітню культурну спадщину [15].У свою чергу, тим же законом визначено, що документ Національного архівного фонду (НАФ) - це архівний документ, культурна цінність якого визнана відповідною експертизою та який підлягає державному обліку і зберіганню [15]. Тобто законодавець передбачив серед цінних документів можливість існування особливо цінних 3 них, зокрема за критерієм унікальності.

Державна архівна служба України, відповідно до Положення [16], організовує роботу, пов'язану з віднесенням документів НАФ до унікальних та включенням їх до Державного реєстру національного культурного надбання.

Віднесення документів НАФ до унікальних здійснюється шляхом їх виявлення, проведення експертизи цінності, опису та внесення до Державного реєстру [17]. Остаточне рішення про визнання документа унікальним та внесення його до Державного реєстру приймається Центральною експертно-перевірною комісією, яка функціонує при Державній архівній службі України на основі заявок, поданих експертно-перевірними комісіями державних архівів.

Архівне законодавство встановило також, що критеріями віднесення документів НАФ до унікальних $є$ походження, зміст та зовнішні ознаки документа. Кожний критерій охоплює певний склад характеристик документа, наявність яких є підставою для його віднесення до категорії унікальних: 
- походження - функціонально-цільове призначення юридичної особи або значення фізичної особи (фондоутворювачів) у житті суспільства (масштаби і значення діяльності цієї особи в системі державного управління, їі ролі в суспільно-політичному, культурному житті тощо), час створення (будь-який оригінал документа, створеного до XVI ст., належить до унікальних), місце та історичні умови створення документа (наприклад, документи, створені за екстремальних обставин);

- зміст - значущість інформації, що міститься в документі (унікальність і типовість);

- зовнішні ознаки - форма фіксації та передачі змісту, особливості оформлення документа.

Крім того, норми українського законодавства встановлюють, що власники унікальних документів НАФ зобов'язані: створити належні умови для їх зберігання; забезпечити виготовлення страхового фонду унікальних документів (на мікроплівці) та фонд користування у вигляді копій (цифрові чи аналогові); забезпечити їх страхування, першочергову реставрацію. До того ж оригінали унікальних документів заборонено видавати до читального залу, експонувати на виставках і копіювати. Усі ці заходи направлені здебільшого для забезпечення збереженості унікальних документів, але не менш важливим завданням роботи архівних установ $\epsilon$ використання архівної інформації. 3 цією метою Державна архівна служба України в березні 2020 року започаткувала на своєму офіційному вебпорталі спеціальну рубрику, де користувачі мають змогу отримати інформацію про унікальні документи НАФ, переглянути онлайн та завантажити їх цифрові копї̈ [9].

Етапи розвитку поняття Унікальний документ Націонахьного архівного фонду

Нормотворча традиція «унікальності» архівної документації походить 3 радянських практик архівної справи та радянського архівного законодавства. Тоталітарна радянська система в архівній сфері полягала передусім у проголошенні примату державного (у номенклатурному розумінні цього поняття) над особистим; дозування доступу до ретроспективної інформації за ідеологічно-політичними ознаками, а здебільшого за ознакою приналежності до цієї номенклатури; наявність кількох державних архівних систем, у тому числі - окремого Архівного фонду КПРС, архівних систем КДБ, МВС, МЗС, військово-промислового комплексу тощо [7, с. 4].

Парадигма позитивної правової системи та домінування ідеологізованої методології відбивалось на підходах держави до зберігання ретроспективної інформації. Окрім окремого функціонування кількох державних архівних систем, самі архівні комплекси (фонди) в державних архівах СРСР ділились на три категорії. Формально поділ фондів на категорії відбувався за принципами «його науково-історичної цінності, всебічності документної інформації, ступеня повноти... ролі, місця і значення установи-фондоутворювача у сфері громадської та державної діяльності..» [18, с. 30]. На практиці це був ще одним механізмом обмеження доступу до архівної інформації, бо важливі інформативні для дослідників, але нецікаві чи «ворожі» для партійної номенклатури, фонди записувались в останню «третю» категорію і залишались десятиліттями неописані, що блокувало доступ до цих архівів на інтелектуальному рівні (відсутність розвинутого довідкового апарату).

Радянським попередником поняття «унікальний документ» був термін «особливо цінний документ». «Інструкція про виявлення, облік, описування та зберігання особливо цінних документів» 1980 року містить наступну дефініцію: «До особливо цінних документів відносяться документи, які містять інформацію про найважливіші події, факти та явища життя суспільства, які мають неминуче значення для державного управління, народного господарства, оборони країни, в міжнародних відносинах, наукових дослідженнях і непоправні при втраті з точки зору їх юридичного значення та авторафічності, а також унікальні документи, які не мають собі подібних за наявною в них інформацією, за способом iї фіксації або за зовнішнім виглядом» [19, c. 3]. Отже, у системі позитивного радянського архівного законодавства домінував 


\section{Теорія, історія держави і права, конституційне право}

утилітарний підхід до особливої цінності документів в інтересах державного управління, оборони, промисловості. Але навіть в самому Головархіві СРСР - тогочасному органі управління радянською архівною системою, визнавали проблему відсутності чіткої визначеності запропонованої архівної категорії: «Це визначення дає лише загальне уявлення про особливо цінні документи і в суворому смислі не $є$ чіткою дефініцією» [20, с. 6]. Також у радянських «Методичних рекомендаціях по роботі 3 особливо цінними документами в державних архівах» 1983 року була спроба роз'яснити відмінності між особливо цінними документами та унікальними, бо ще з 1958 року в роботі радянських державних архівів відчувалось протиставлення цих груп документів одна одній. Була запропонована робоча модель, за якою «унікальні документи - це особливо цінні документи більш високого рівня» [20, с. 7], але єдиною робочою назвою мала залишатися назва «особливо цінні документи».

У зарубіжній архівній теорії та практиці активно застосовувалися терміни «унікальність інформації та документа» в архівах СІІА[21], «унікальний акт» у Польщі [22] тощо. Поняття «унікальний документ» чи аналогічний термін 3 епітетом «унікальний» $є$ ближчим до доктрини природнього права, адже свідчить про явище, культурну пам'ятку, яка за своєю суттю, природою не схожа на інші і має важливе значення для розвитку народу. В той же час «особливо цінний документ» 6 насправді лише констатацією вимог збереження в публічній установі, плід позитивної нормотворчості.

Після здобуття незалежності Україною розпочався процес лібералізації архівного законодавства. Зокрема, ці зрушення в нормотворчості торкнулись і категорії унікальних архівних документів, яка прийшла на заміну радянського визначення особливо цінних документів. Пізніше, у 1998 році вийшов спільний наказ Головного архівного управління при Кабінеті Міністрів України та Національної академії наук України від 19 листопада 1998 року № 73/29 «Про затвердження Методики і критеріїв виявлення і включення унікальних докумен- тальних пам'яток Національного архівного фонду України до Державного реєстру національного культурного надбання» [23]. Цей нормативно-правовий акт дає нову дефініцію «унікальна документальна пам'ятка» і визначає її як «особливо цінний документ Національного архівного фонду, який має важливе значення для формування національної самосвідомості українського народу, визначає його вклад у всесвітню культурну спадщину, не має собі подібних i щодо юридичної сили, автографічності та зовнішніх ознак не може бути відновлений у разі непоправного пошкодження або втрати» [23]. Відтоді в українській архівній нормотворчості закріпився примат природньої якості унікальності над визначених державою характеристики особливої цінності. Пізніше [17] термін був скорегований до сучасного «унікальний документ НАФ», що відображено в чинних нормативно-правових актах.

Унікальна пам'ятка Національних архівних інформаційних ресурсів

Розвиток постіндустріального, інформаційного суспільства створюе нові виклики для роботи архівів та архівістів. Різноманітні технократичні структури продукують інформаційні потоки даних, які постійно конкурують між собою за право бути збереженими, хоча вже зараз абсолютна більшість 3 них (до 95\% всієї інформації) перебувають поза зоною можливого контролю 3 боку людини [24, с.35]. Нові виклики потребують змін до зберігання архівної інформації, експертизи цінності документації, структури та облаштування архівів, освіти та перепідготовки архівістів та, очевидно, зміни до архівного законодавства. У ряді цих питань і постає дилема щодо правової визначеності поняття унікальний документ НАФ. Вслід за домінуванням характеристики «унікальний» над «особливо цінний» в архівному науковому та законодавчому наративі, останні десятиліття можна відстежити активне просування поняття «інформаційний ресурс» у наукових працях спеціалістів з проблем інформаційного права: А. Марущака [25], [26], [27], О. Юдіна та С. Бучика [28], Й. Мастяниці [29], О. Олійника [30], О. Сидоренка [31], О. Довганя 
[32], Ю. Приймака [32], О. Сосніна [34] та інших. Також дефініція «інформаційний ресурс» з'являється в українських нормативних актах поряд, а частіше на заміну поняття «документ» [35], [36], [37]. Застосування терміну «інформаційні ресурси» до комплексів архівної документації може розширити можливості державних архівів в комплектуванні, обліку та використанні архівної інформації, ця ідея вже неодноразово висувалась у наукових роботах учених-архівознавців [38], [39], [40], [41].

Практика роботи Центральної експертно-перевірної комісії при Державній архівній службі України свідчить про низку проблем при опрацюванні заявок архівів щодо віднесення документів до унікальних. Правова невизначеність, фактор персонального складу комісії та керівництва служби може впливати на ухвалення позитивного рішення чи відхилення заявок. Це поле для ухвалення волюнтаристських чи політично, ідеологічно вмотивованих рішень. Так, чинним нормативним актом встановлено [17], що до унікальних можуть бути віднесені лише окремі документи Національного архівного фонду. Це фактично унеможливлює одноразове віднесення до унікальних цілої архівної справи чи групи одиниць зберігання, які логічно є пов'язаними та в комплексі формують критерії своєї унікальності.

Вирішенням проблеми правової визначеності поняття «унікальний документ Національного архівного фонду» може стати впровадження нової дефініції, яка 6 увібрала в себе історичні передумови розвитку архівної справи та сучасні підходи доступу до інформаційних ресурсів. Ним може стати поняття «унікальна пам'ятка Національних архівних інформаційних ресурсів», як така, що найбільш чітко але в той же час широко окреслює специфіку зазначеної категорії архівного надбання:

Унікальна пам'ятка Національних архівних інформаційних ресурсів - єдиний у своєму роді особливо цінний інформаційний ресурс, документ, артефакт у складі Національних архівних інформаційних ресурсів, що відіграє особливо важливе значення у формуванні національної самосвідомості
Українського народу та визначає його внесок у всесвітню культурну спадщину.

\section{Висновки}

1. Серед десятків мільйонів одиниць зберігання в сховищах державних архівів України експертизою виявлено майже півтисячі документів зі статусом «унікальні». Для збереження цієї групи культурного надбання українського народу встановлено особливі умови зберігання, обліку, виявлення та використання. Водночас проблема правової невизначеності гальмує процес наповнення реєстру унікальних документів та призводить до різночитання підходів виявлення подібних пам'яток.

2. Вітчизняна та західна історіографія, а також історія розвитку архівного законодавства на українських територіях свідчать про детерміновану боротьбу наступних категорій: «особливо цінні документи - унікальні пам'ятки, документи» та «архівні фонди - архівні інформаційні ресурси».

3. Сучасні виклики інформаційної трансформації суспільства, а також проблему правової визначеності поняття «унікальний документ Національного архівного фонду» запропоновано вирішити шляхом впровадження нової юридичної категорії «унікальна пам'ятка Національних архівних інформаційних ресурсів».

\section{Конфлікт інтересів}

Автори заявляють про відсутність конфлікту інтересів.

\section{Вираз вдячності}

Робота виконана в ініціативному порядку та не отримувала жодного фінансування.

\section{Література}

1. Козюбра М. I. Верховенство права і Україна. Право України. 2012. №№ 1-2. C. 30-63.

2. Мусиченко О. Зрозумілість і чіткість закону як складова частина принципу правової визначеності в практиці Європейського суду з прав людини. Visegrad Journal of Human rights. 2016. №№ 1-2. C. 149-153.

3. Погребняк С. П. Принцип правової визначеності як загальний принцип права. Антропологія права: філософський та юридичний виміри (стан, проблеми, пер- 


\section{Теорія, історія держави і права, конституційне право}

спективи) : статті учасників міжн. круглого столу. Аьвів 3-5 грудня 2010 р. Аьвів : Галицький друкар, 2010. С. 490-508.

4. Огнев'юк Г.З. Правова визначеність як юридична категорія. Бюлетень Міністерства юстиції України. 2017. № 10. С. 3235 .

5. Архівістика: термінологічний словник / Голов. архів. упр. при КМУ, УДНДІАСД; авт.-упоряд.: К. С. Новохатський (кер. авт. кол.), К. Т. Селіверстова (заст. кер.),Н. І. Гончарова [та ін.]. Київ, 1998. 105 с.

6. Матяш I. Б. Методологічні засади й понятійний апарат архівознавства. Украӥнсъкий історичний журнал. 2009. № 2. С. 124134.

7. Боряк Г.В., Новохатський К.Е. Модерне архівне законодавство України. Архіви Украӥни. 2004. № 3(254). С. 4-10.

8. Доклад о верховенстве права / Европейская комиссия за демократию через право (Венецианская комиссия). URL: http://www.venice.coe.int/docs/ 2011/ CDL'AD(2011)003rev'rus.pdf.

9. Унікальні документи Національного архівного фонду України: рубрика офіційного порталу Державної архівної служби України. URL: https://archives.gov. ua/?uniq $=1 \& \mathrm{~s}=$ [станом на 10.12.2020 p.].

10. Хромов А.В. Унікальні документи Національного архівного фонду державних архівів Півдня України. Південь України у вітчизняній та європейській історії: матеріали V Міжнародної науково-практичної конференції (17-18 вересня 2020 р., м. Одеса). Одеса: Екологія, 2020. С. 20-26.

11. Центральний державний історичний архів України, м. Аьвів. Ф. 131. Оп. 1. Спр. 891.

12. Центральний державний історичний архів України, м. Аьвів. Ф. 131. Оп. 1. Спр. 892.

13. Центральний державний історичний архів України, м. Львів. Ф. 131. Оп. 1. Спр. 893.

14. Центральний державний архів вищих органів влади та управління України. Ф. 1. Оп. 16. Спр. 5466.

15. Про Національний архівний фонд та архівні установи: Закон України від 24.12.1993 р. № 3814-XII (в редак- ції від 16.10.2020р.). URL: https://zakon. rada.gov.ua/laws/show/3814-12 [станом на 10.12.2020 p.].

16. Про затвердження Положення про Державну архівну службу України: Постанова КМУ від 21.10.2015 р. № 870 (в редакції від 18.02.20 р.). URL: https://zakon. rada.gov.ua/laws/show/870-2015-п [станом на 10.12.2020].

17. Про проведення експертизи цінності документів: Постанова КМУ від 08.08.2007 р. № 1004 (в редакції від 04.11 .2016 p.). URL: https://zakon.rada. gov.ua/laws/show/1004-2007-п [станом на 10.12.2020 p.].

18. Основные правила работы государственных архивов СССР / Главное архивное управление при Совете Министров СССР. Москва, 1984. 240 с.

19. Инструкция о выявлении, учете, описании и хранении особо ценных документов / Главное архивное управление при Совете Министров СССР. Москва,1980. $19 \mathrm{c}$.

20. Методические рекомендации по работе с особо ценными документами в государственных архивах/ Главное архивное управление при Совете Министров СССР. Москва., 1983.35 с.

21. Левченко $\mathcal{\Lambda}$.А. О развитии теории экспертизы ценности документов в США (от профессиональной методологии к социальной эпистемологии). Перспективы науки. 2014. № 2(53). С. 101-113.

22. Аевченко $\lambda$. $\lambda$. Видатний польський архівіст Густав Каленський та його праця «Brakowanie akt». Архіви україни. 2014. № 4-5. C. 281-317.

23. Про затвердження Методики і критеріїв виявлення і включення унікальних документальних пам'яток Національного архівного фонду України до Державного реєстру національного культурного надбання: спільний наказ Головного архівного управління при Кабінеті Міністрів України та Національної академії наук України від 19.11.1998 p. № 73/29. URL: https://zakon. rada.gov.ua/laws/show/z0201-08\#Text [станом на 10.12.2020].

24. Бездрабко В.В. Теоретичні засади експертизи цінності документів: традиції і 
сучасні тренди (із зарубіжного досвіду). $A p$ хіви Украӥни. 2019. № 4. С. 7-42.

25. Марущак А. I. Інформаційне право: доступ до інформації : навч. посібн. Київ: КНТ, 2007. 532 с.

26. Марущак А. I. Інформаційні ресурси держави: зміст та проблема захисту. Правова інборматика. 2009. № 1 (21). С. 64-70.

27. Марущак А. I., Петров С. Г. Зміст поняття державні електронні інформаційні ресурси. Інформачія і право. 2018. № 4 (27). C. $15-21$.

28. Юдін О. К., Бучик С. С. Державні інформаційні ресурси. Методологія побудови класифікатора загроз : монографія. Київ: НАУ, 2015. 214 с.

29. Мастяниця Й. І. Інформаційні ресурси України: проблеми державного регулювання : монографія. Київ: НІСТ, 2006. $141 \mathrm{c}$.

30. Олійник О.В.Організаційно-правові засади захисту інформаційних ресурсів України: Дис. канд. юрид. наук: 12.00.07. Київ, 2006. 201 с.

31. Сидоренко О. Інформаційні ресурси як об'єкт інформаційних правовідносин. Інформаційне право. 2018. № 4. С. 173-182.

32. Довгань О. Д. Інформаційні ресурси: національні та державні, зміст, поняття. Інформачія і право. 2015. № 3 (15). С. 85-91.

33. Приймак Ю. Ю. Механізми управління Національними інформаційними ресурсами України і електронному урядуванні. Автореф. дис... канд. наук 3 держ. упр. Київ, 2012. 23 с.

34. Соснін О. В. Національні інформаційні ресурси: проблеми визначення і розуміння. Стратегічна панорама. 2004. № 4. C. 141-146.

35. Про Концепцію Національної програми інформатизації: Закон України від 04.02.1998 р. № 75/98-BP ( в редакції від 03.07.2020 р.). URL: https://zakon. rada.gov.ua/laws/show/75/98-вр [станом на 10.12.2020].

36. Про затвердження концепція формування системи національних електронних інформаційних ресурсів: Розпорядження Кабінету Міністрів України від 5 травня 2003 р. № 259-p. URL: https://za-
kon.rada.gov.ua/laws/show/259-2003-p\#Text [станом на 10.12.2020].

37. Про Державну службу спеціального зв'язку та захисту інформації України: Закон України від 23.02. 2006 р. № 3475-IV (в редакції від 16.10.2020). URL: https://zakon. rada.gov.ua/laws/show/3475-15 [станом на 10.12.2020].

38. Боряк Г. В. НАIC і проблеми доступу до архівної інформації в документальних архівних та інформаційних системах. Національна архівна інформаційна система «Архівна та рукописна Україніка». Випуск 1. Інформатизація архівної справи в Україні: сучасний стан та перспективи. 36. наук. праць. Київ, 1996. С. 19-40.

39. Спасенова Ю. М. Термінологічний аналіз понять «інформаційні архівні ресурси» й «електронні архівні ресурси». Вісник ХДАК. 2014. Вип. 43. С. 126-135.

40. Віднесення електронних інформаційних ресурсів до Національного архівного фонду. Аналітичний огляд / Держ. архівна служба України; Укр. наук.-досл. ін-т архів. справи та документознавства; уклад.: Т. М. Ковтанюк, Н. М. Христова. Київ, 2012. 33 c.

41. Кисельова А. А. Архівні ресурси України в глобальній інформаційній мережі : види, доступ, перспективи : Автореф. дис. ... канд. іст. наук. Київ, 2005. 19 с.

\section{Popova L.M., Khromov A.V. THE PROBLEM OF LEGAL GERTAIN- TY OF UNIQUE DOCUMENTS OF THE NATIONAL ARCHIVAL FUND}

Problem statement. The concept of "Unique document of the National Archival Fund" is one of the main in the categorical apparatus of archivists of Ukraine. One of the key tasks of the state archives network, the State Archival Service of Ukraine is the constant selection, approval of the status and ensuring the registration and preservation of unique documents of the National Archival Fund (NAF). The realities of such work state the problems of insufficient legal certainty of this category. The purpose of the research is to characterize and analyze the mechanism of classifying NAF documents as unique, their 


\section{Теорія, історія держави і права, конституційне право}

\section{АНОТАЦІЯ}

Поняття «Унікальний документ Національного архівного фонду» $е$ одним із основних у категоріальному апараті архівістів України. Одним із ключових завдань мережі державних архівів, Державної архівної служби Украйни є постійний відбір, затвердження статусу та забезпечення обліку та збереження унікальних документів Національного архівного бонду (НАФ). Реалї такої роботи констатують наявність проблеми недостатньої правової визначеності иієї категоpiï. Метою дослідження є характеристика та аналіз механізму віднесення документів НАФ до унікальних, їх обліку та зберігання. Результат дослідження полягає в обгрунтуванні необхідності внесення змін до категоріального апарату галузевого архівного закону та підзаконних актів. Висновки. Встановлено, що після здобуття Украӥною незалежносmі законодавию знадобилося більше 2 років для ухвалення пробільного архівного закону, яким, зокрема визначено окрему категорію унікальних документів НАФ. Ця достатньо вузъка група історичних пам'яток має важливе значення для розвитку архівної галузі країни, водночас механізм віднесення архівних документів до НАФ є недосконалим, у тому числі через проблему недостатньої правової визначеності понять. Для вирішення иієї проблеми запропоновано в архівне законодавство ввести нове поняття «унікальна пам'ятка Національних архівних інбормаизйних ресурсів».

Ключові слова: унікальний документ, унікальна пам'ятка, Національний архівний бонд, Національні архівні інбормачійні ресурси, правова визначеність, Державна архівна служба України, експертиза иінності. accounting and storage. Research methods. A systematic method was used (to clarify the place of the concept of "unique NAF document" in the system of archival legislation of Ukraine), general comparative and special comparative legal and comparative-historical methods (to compare the meaning of legal terms in different stages of Soviet and Ukrainian archival legislation, as well as to compare the practices of archival systems of foreign countries). Formal legal method is used to comprehensively characterize the main legal categories of archival legislation of Ukraine. The method of scientific interpretation of law is used to clarify the content of relevant legal norms. The result of the research is to substantiate the need for changes in the categorical apparatus of the branch archival law and bylaws. Conclusions. It was established that after Ukraine gained independence, the legislator took more than 2 years to adopt a profile archival law, which in particular defines a separate category of unique NAF documents. This rather narrow group of historical monuments is important for the development of the country's archival industry. At the same time, the mechanism for classifying archival documents as NAF is imperfect. In particular, there is a problem of insufficient legal certainty of concepts. To solve this problem, it is proposed to introduce a new concept of "unique monument of National Archival Information Resources" in the archival legislation.

Keywords: unique document, unique monument, National Archival Fund, National Archival Information Resources, legal certainty, State Archival Service of Ukraine, value examination. 